\title{
IMPORTANCE OF COMPOST FERTILIZATION AND SPRAYING WITH MORINGA LEAF EXTRACT ON YIELD AND QUALITY OF CHERRY TOMATO UNDER ORGANIC SOILLESS SYSTEM
}

\author{
M. Nour El-Din(1), H.M. El-Koumy(2) and M.H. El-Bagory(1) \\ (1) Soil, Water and Environmental Research Institute, ARC, Egypt. \\ (2) Vegetable Research Department, Hort. Res. Inst., Agric. Res. Center, Giza, Egypt. \\ Received: May 8, 2018 \\ Accepted: Jun. 24, 2018
}

\begin{abstract}
Soilless agriculture is one of the most promising systems because its advantages like saving irrigation water, benefiting from unsuitable land for agriculture or agriculture of building roofs for production of food as well as decreasing pesticide application or mineral fertilizers. Organic fertilization contributes also in decreasing hazardous side effects of using chemical fertilizers.

The aiming of this investigation was to study of using organic fertilization system by adding compost as a source of fertilizer, irrigate the plants with fish extract at rate of 1:100 and spraying the plants with moringa leaf extract and the influence of that on cherry tomato plant growth, fruit yield and its quality.

The results of the present investigation showed that compost application in vermiculite improved yield and quality of cherry tomato fruits (Guindo $F_{1}$ ), especially at 400 and 500 g/plant levels, which increased plant length, number of leaves and leaf area/plant, total fruit yield, average fruit weight, fruit diameter, vitamin $C, T S S, N, P$ and $K$ percentages. While decreased the stem thickness, and titratable acidity percentage in tomato fruits.

Foliar application with moringa leaf extract exhibited a positive influence on the previous studied parameters. The interactions between organic fertilization and moringa leaf extract highly increased these parameters. The highest total fruit yield was obtained from $400 \mathrm{~g}$ compost/plant as well as fertigation with fish extract and sprayed with moringa leaf extract, it gave 5.436 and 5.054 fruits $\mathrm{kg} / \mathrm{plant}$ compared to the control treatment (chemical fertilization, without moringa leaf extract spray) which obtained 3.765 and $4.201 \mathrm{~kg} / \mathrm{plant}$ for the first and the second season, respectively.
\end{abstract}

Key words: Soilless agriculture, organic fertilization, compost, fish extract, moringa extract, cherry tomato.

\section{INTRODUCTION}

Cherry tomato is an important vegetable crop characterized with their sweet taste and nutrient value, whereas, it contains lycopene, vitamins C, A, B and nutrient elements (Pinho et al., 2011). Cherry tomato planted in large scale environmental conditions in open field and protected agriculture systems (Abd El-Razzak et al., 2016).

Vermiculite sometimes used in agriculture of tomato under greenhouse or top roofs. Vermiculite characterized with light weight, high water capacity, sterilized, free from soil porn diseases and nematodes (Olle et al., 2012). Therefore, this planting media is suitable for top roof agriculture. In Egypt, about 4 million building, possessed if it is used for producing vegetable, they will improve the natural income. Organic nutrition of plants grown in soilless system is more acceptable especially for top roof agriculture as well as for exporting. Most of important organic nutrient solution is the fish extract synthesis from residues of home fish and the residues of fish industrialization, it contains high amount of macro and micro elements, in addition 
to amino acids (Zahi, 2009). Compost used also in organic fertilization, it contains a high levels of macro and micro elements. Compost characterized with low density, high water capacity and free from nematodes and soil porn diseases.

Vegetable plants usually sprayed with plant phytohormones like gebrilline and cytokinen to increase plant growth and enhancing yield and its quality. The moringa extract is considered a natural plant growth regulator, where, it is a source of zeatin which is a natural derivative of cytokinin, proteins, vitamin $E$, phenols, ascorbates and essential amino acids as well as several mineral elements, which is potentially stimulate plant growth and yield (Howladar, 2014 and Rady et al., 2015).

The aim of the present study is to investigate the influence of organic fertilization fish residues extract and foliar application of moringa leaves extract on growth, yield and fruit quality of cherry tomato plants.

\section{MATERIALS AND METHODS}

\section{Vermiculite:}

Vermiculite is a mineral of soil originated from mined rocks that is heated to produce the final product.

Moringa extract were prepared by crushed $10 \mathrm{~kg}$ of fresh moringa leaves in 1 liter water, then filtered, the liquid extract was to concentration of $3 \%$ (Muhamman and Mohamed, 2014).

\section{Fish extract:}

The fish extract was made by weighing $10 \mathrm{~kg}$ of fish residues in $100 \mathrm{~L}$ closed container, about $40 \mathrm{~L}$ of water, $250 \mathrm{~g}$ of compost and $200 \mathrm{ml}$ molasses. Air pump operated for aerating the mixture. The aerobic fermentation process was continued for 20 days. One liter of the liquid hydrosates was mixed with $20 \mathrm{~L}$ of water for irrigation the tomato plants. The chemical analysis of fish extract was shown in (Table 1).

\section{Compost:}

Compost was prepared by mixing of rice straw with farmyard manure, the characteristics of applied compost was found in Table (2).

\section{Nutrient solution:}

Composed of different macro and micro-nutrients as formulated by Tzertzakis and Economakis (2008).

\section{METHODS:}

Two pots experiments were carried out at Sakha Agriculture Research Station during the winter season of 2015/2016 and 2016/2017. To investigate the effect of organic fertilization (compost irrigated with fish extract), foliar spraying with moringa leaf extact and their interactions on growth, yield and fruit quality of cherry tomato Guindo $F_{1}$. The seedlings were transplanted on 25 and 20 October in the first and the second seasons, respectively. Split plot design with four replicates was used. The main plots were allocated for two moringa treatments (sprayed with moringa extract and sprayed with water only), the sub plots were assigned to six treatments, chemical fertilization (control) and five treatments of organic fertilization (fish extract with different levels of compost i.e. 100, 200, 300,400 or $500 \mathrm{~g} /$ /plant), these rates were mixed with vermiculite.

Table (1): Chemical analysis of fish extract

\begin{tabular}{|l|c|}
\hline Characters & Value (ppm) \\
\hline Total N & 2068.8 \\
\hline Total P & 562.0 \\
\hline Total K & 432.9 \\
\hline
\end{tabular}


Table (2): Characteristics of applied compost

\begin{tabular}{|l|l|}
\hline Parameters & FYM 4\%Rs \\
\hline $\mathrm{pH}$ & 8.26 \\
\hline EC & 4.80 \\
\hline Organic carbon $(\%)$ & 30.08 \\
\hline Bulk density $\left(\mathrm{kg} / \mathrm{m}^{3}\right)$ & 632 \\
\hline Moisture content & 32 \\
\hline C/N ratio & 16.53 \\
\hline $\mathrm{N} \%$ & $1.82+0.14$ \\
\hline $\mathrm{P} \%$ & $0.79+0.0$ \\
\hline $\mathrm{K} \%$ & $1.44+0.39$ \\
\hline Germination $\%$ & $86.8+0.5$ \\
\hline TCB at $30^{\circ} \mathrm{C}$ & $31 \times 10^{5}$ \\
\hline TCB at $50^{\circ} \mathrm{C}$ & $48 \times 10^{3}$ \\
\hline TCA at $30^{\circ} \mathrm{C}$ & $47 \times 10^{3}$ \\
\hline TCA at $50^{\circ} \mathrm{C}$ & $55 \times 10$ \\
\hline TCF at $30^{\circ} \mathrm{C}$ & $33 \times 10^{3}$ \\
\hline TCF at $50^{\circ} \mathrm{C}$ & $17 \times 10$ \\
\hline E. coli & 0.0 \\
\hline Salmonella sp & 0.0 \\
\hline Shigella sp. & 0.0 \\
\hline
\end{tabular}

TCB: Total content of bacteria

TCA: Total content of actinomycetes

TCF: Total content of fungi

\section{Planting:}

The vermiculite media was backing in polyethylene bags, about $2.5 \mathrm{~kg}$ vermiculite per bag. This media was washed with tap water several times, then the tomato seedlings were planted as one seedling in each bag. Plants were arranged in rows at a distance of $50 \mathrm{~cm}$ between plants to give 2.5 plants $/ \mathrm{m}^{2}$ after that, seedlings were irrigated with tap water for three days. The irrigation with fish extract solution started after three days of planting.

The control plants were irrigated with chemical nutrient solution as formulated by (Tzertzakis and Economakis, 2008). The plant inflated buds were brunning periodically till $60 \mathrm{~cm}$ tall. After that, plants were grown vertically on two branches. The nutrition dose was changed after each planting phase (seedling, flowering, fruiting and aging). The pests and plant diseases were controlled by the spray with micronic sulfur (2.5 g/liter), two times weekly. The pest worm and eggs were handling collected when they watched on the plant leaves.

\section{The plant samples:}

Three plants were taken from each sub plot at 85 days after transplanting for measurement, number of leaves/plant, leaf area/plant $\left(\mathrm{cm}^{2}\right)$ was determined according to the formula:

leaf area $\left(\mathrm{cm}^{2}\right)=$

$\frac{\text { fresh weight of leaves }}{\text { fresh weight of discs }} x$ area of discs, stem thickness $(\mathrm{mm})$ and stem length (cm), i.e. vegetative growth parameters. 
Fruit yield:

Ripening tomato fruits were collected two times every week and weighed. The early fruit yield was determined for the first five pickings, but the total yield was estimated for the total pickings till the end of the fruiting season.

\section{Fruit characters and quality:}

Ten fruits from each sub-plot were taken randomly to determine fruit diameter, average fruit weight, total soluble solids (TSS\%) by a hand refractometer according to A.O.A.C., vitamin C content (ascorbic acid) by titration with 2, 6-Di-chlorophenol endophenol according to A.O.A.C., N,P and $K$ contents of fresh tomato fruits. Total $\mathbf{N}$ was determined using the microkjeldahl method (Pregel, 1945). Total phosphorus was determined colorimetrically using a spectrophotometer at $650 \mathrm{~mm}$ (King, 1951). Total potassium was determined using flame photometer as described by Jackson and Strelec (1967).

\section{RESULTS}

Vegetative growth:

Data of Table (3) indicated that spraying the plants with moringa leaf extract significantly increased leaves number of the plant. This effect was similar for both studying seasons. Moringa extract exhibited $\mathbf{3 8 . 2 2}$ and $\mathbf{3 8 . 9 3}$ leaves/plant compared to $\mathbf{3 7 . 2 8}$ and $\mathbf{3 6 . 2 0}$ for control without moringa extract at the first and the second seasons, respectively. The results showed also that, organic fertilization with fish extract (dilution 1:100) with compost levels added to vermiculite soilless culture variably affected on leaves numbers of cherry tomato plants, where, $300 \mathrm{~g} / \mathrm{plant}$ compost gave the highest number of leaves per plant (39.5) which was similar to chemical fertilized control (without compost, and fish extract which gave
39.5). However, the data of the second season (2016/2017) showed non significant differences between the levels of compost addition. Data of interaction between moringa extract and compost levels did not show significant effect, regarding number of leaves/plant.

Results in Table (3) illustrated the leaf area of plant as affected by moringa extract spray. The spraying with moringa extract gave slight increase in leaf area, no significant difference with non sprayed control plants. The data of the second season followed the same trend of the first one.

Application of compost levels with fish extract, otherwise, had a noticeable effect on leaf area/plants. The leaf area of cherry tomato plants increased with increasing of the compost levels. The highest values in the first season showed that 400 and 500 gm compost per plant, which gave 6778.65 and 7079.5 compared to 5613.28 $\mathrm{cm}^{2}$ /plant for the chemical treatment (without compost). The differences were significant. In the second season, the treatment of $500 \mathrm{gm}$ compost gave the highest values of the leaf area, it attained $6955.33 \mathrm{~cm}^{2}$ /plant compared to 5419.93 for the control (without organic fertilization), and the difference was significant.

Nevertheless, the interactions between the moringa foliar spraying and compost levels with fish extract had no significant variations, the highest values (7216.6 and 7183.6) at the first and the second seasons which obtained with moringa spray and $\mathbf{5 0 0} \mathbf{g m}$ compost addition.

Concerning to stem thickness, it was found that spraying with moringa extract significantly increased stem thickness of tomato (Table 4). The mean value of plant thickness for moringa extract spray was 11.36 compared to $11.09 \mathrm{~mm}$ for control plants. At the second season, there was a similar trend as the first one. 
The type of fertilization clearly affect of the stem thickness, where, fertilization with fish extract in combination with different levels of compost gave low records than chemical fertilized plants. On the other hand, increasing the levels of compost caused noticeable in the stem thickness. The level of $100 \mathrm{~g} / \mathrm{plant}$ gave $9.72 \mathrm{~mm}$, while $500 \mathrm{~g}$ compost/plant gave $10.93 \mathrm{~mm}$. The differences due to compost levels were significant. At the second season, the treatments gave the same trend on stem thickness as the first one.

The combined effect between moringa extract spray and organic fertilization had no significant effect through the two growing seasons.

Regarding to stem length, data in Table (4) sowed that, moringa extract spraying significantly increased stem length of tomato plants over not sprayed plants. The mean length of sprayed plants at the first season was $213.83 \mathrm{~cm}$ compared to $210 \mathrm{~cm}$ for not sprayed one. This treatment similarly affected on the plant length at the second season, whereas, sprayed plants with moringa significantly increased to reach (214.17) than not sprayed plants $(209.78 \mathrm{~cm})$.

Table (3): Effect of foliar application of the moringa leaves extract and organic fertilization on number of leaves/plant and leaf area $\mathrm{cm}^{2} /$ plant of cherry tomato plants.

\begin{tabular}{|c|c|c|c|c|c|c|c|}
\hline \multirow{4}{*}{ Organic fert. } & \multirow[t]{2}{*}{ Ch.1 } & \multicolumn{6}{|c|}{ Fish extract + compost (g/plant) } \\
\hline & & 100 & 200 & 300 & 400 & 500 & Mean \\
\hline & \multicolumn{7}{|c|}{ Number of leaves } \\
\hline & \multicolumn{7}{|c|}{ First season (2015/2016) } \\
\hline Moringa & 40.33 & 37.33 & 35.00 & 40.00 & 37.33 & 39.33 & $38.22 \mathrm{a}$ \\
\hline Without & 38.67 & 36.33 & 34.33 & 39.00 & 36.67 & 38.67 & $37.28 \mathrm{~b}$ \\
\hline Means & $39.50 \mathrm{a}$ & $36.83 \mathrm{~b}$ & $34.67 \mathrm{c}$ & $39.50 \mathrm{a}$ & $37.00 \mathrm{~b}$ & $39.00 \mathrm{ab}$ & \\
\hline \multirow[t]{2}{*}{ F. test } & \multicolumn{7}{|c|}{$M=*, C=* *, M \times C=N S$} \\
\hline & \multicolumn{7}{|c|}{ Second season $(2016 / 2017)$} \\
\hline Moringa & 39.40 & 37.10 & 36.50 & 38.57 & 39.03 & 42.97 & $38.93 \mathrm{a}$ \\
\hline Without & 37.63 & 37.30 & 33.57 & 37.77 & 35.93 & 35.00 & $36.20 \mathrm{~b}$ \\
\hline Means & 38.52 & 37.20 & 35.03 & 38.17 & 37.48 & 38.98 & \\
\hline \multirow[t]{3}{*}{ F. test } & \multicolumn{7}{|c|}{$M=*, C=N S, M \times C=N S$} \\
\hline & \multicolumn{7}{|c|}{ Leaf area/plant $\left(\mathrm{cm}^{2}\right)$} \\
\hline & \multicolumn{7}{|c|}{ First season (2015/2016) } \\
\hline Moringa & 5665.00 & 4337.47 & 5042.23 & 5457.53 & 6914.77 & 7216.60 & 5772.27 \\
\hline Without & 5561.57 & 4576.57 & 4967.77 & 5331.43 & 6642.53 & 6942.40 & 5670.40 \\
\hline Means & $5613.28 \mathrm{~b}$ & $4457.02 \mathrm{~d}$ & $5005.00 \mathrm{~cd}$ & $5394.48 \mathrm{bc}$ & $6778.65 \mathrm{a}$ & $7079.50 \mathrm{a}$ & \\
\hline \multirow[t]{2}{*}{ F. test } & \multicolumn{7}{|c|}{$M=N S, C=* *, M \times C=N S$} \\
\hline & \multicolumn{7}{|c|}{ Second season (2016/2017) } \\
\hline Moringa & 5519.57 & 4562.67 & 5096.27 & 5383.50 & 6691.67 & 7183.60 & 5739.54 \\
\hline Without & 5320.30 & 4200.63 & 4935.20 & 5235.03 & 6516.93 & 6727.07 & 5489.19 \\
\hline Means & $5419.93 \mathrm{~b}$ & $4381.65 \mathrm{c}$ & $5015.73 \mathrm{~b}$ & $5309.27 \mathrm{~b}$ & $6604.30 \mathrm{~b}$ & $6955.33 \mathrm{a}$ & \\
\hline F. test & \multicolumn{7}{|c|}{$M=N S, C={ }^{* *}, M \times C=N S$} \\
\hline
\end{tabular}


Table (4): Effect of foliar application moringa leaves extract and organic fertilization on stem thickness $(\mathrm{mm})$ and stem length $(\mathrm{cm})$ of cherry tomato plants.

\begin{tabular}{|c|c|c|c|c|c|c|c|}
\hline \multirow{4}{*}{ Organic fert. } & \multirow[t]{2}{*}{ Ch.1 } & \multicolumn{6}{|c|}{ Fish extract + compost (g/plant) } \\
\hline & & 100 & 200 & 300 & 400 & 500 & Mean \\
\hline & \multicolumn{7}{|c|}{ Stem thickness (mm) } \\
\hline & \multicolumn{7}{|c|}{ First season (2015/2016) } \\
\hline Moringa & 13.53 & 9.83 & 10.67 & 11.03 & 12.03 & 11.03 & $11.36 \mathrm{a}$ \\
\hline Without & 13.10 & 9.60 & 10.40 & 10.80 & 11.80 & 10.83 & $11.09 \mathrm{~b}$ \\
\hline Means & $13.32 \mathrm{a}$ & $9.72 \mathrm{~d}$ & $10.53 \mathrm{c}$ & $10.92 \mathrm{c}$ & $11.92 \mathrm{~b}$ & $10.93 \mathrm{c}$ & \\
\hline \multirow[t]{2}{*}{ F. test } & \multicolumn{7}{|c|}{$M=* *, C=* *, M \times C=N S$} \\
\hline & \multicolumn{7}{|c|}{ Second season $(2016 / 2017)$} \\
\hline Moringa & 12.40 & 9.70 & 10.50 & 10.77 & 11.57 & 11.23 & 11.03 \\
\hline Without & 11.77 & 9.43 & 10.10 & 10.53 & 11.37 & 11.20 & 10.73 \\
\hline Means & $12.08 \mathrm{a}$ & $9.57 \mathrm{~d}$ & $10.30 \mathrm{c}$ & $10.65 \mathrm{c}$ & $11.46 \mathrm{~b}$ & $11.22 \mathrm{~b}$ & \\
\hline F. test & \multicolumn{7}{|c|}{$M=N S, C=* *, M \times C=N S$} \\
\hline & \multicolumn{7}{|c|}{ Stem length (cm) } \\
\hline & \multicolumn{7}{|c|}{ First season $(2015 / 2016)$} \\
\hline Moringa & 208.03 & 215.90 & 211.37 & 209.93 & 217.13 & 220.60 & $213.83 \mathrm{a}$ \\
\hline Without & 206.70 & 210.77 & 208.30 & 208.27 & 214.93 & 214.70 & $210.00 \mathrm{~b}$ \\
\hline Means & 207.37 & 213.33 & 209.83 & 209.10 & 216.03 & 217.65 & \\
\hline \multirow[t]{2}{*}{ F. test } & \multicolumn{7}{|c|}{$M=*, C=N S, M \times C=N S$} \\
\hline & \multicolumn{7}{|c|}{ Second season $(2016 / 2017)$} \\
\hline Moringa & 206.67 & 215.00 & 214.67 & 211.33 & 216.00 & 221.33 & $214.17 \mathrm{a}$ \\
\hline Without & 202.67 & 210.33 & 211.00 & 208.00 & 212.00 & 214.67 & $209.78 \mathrm{~b}$ \\
\hline Means & $204.67 \mathrm{c}$ & $212.67 a b$ & $212.83 a b$ & $209.67 \mathrm{~b}$ & $214.00 \mathrm{ab}$ & $218.00 \mathrm{a}$ & \\
\hline F. test & \multicolumn{7}{|c|}{$M=*, C={ }^{* *}, M \times C=N S$} \\
\hline
\end{tabular}

${ }^{*},{ }^{*}$ and NS indicate significant differences at $\mathrm{P}<0.01, \mathrm{P}<0.05$ and Not significant, respectively according to F-test.

In the same column, means followed by same letter are not significantly different at $5 \%$ level according to Duncan's test.

Otherwise, organic fertilization with fish extract and compost levels affect differently than chemical fertilization. The chemical fertilization gave lower the records than those of organic fertilization. For example, at the first season, the mean record of stem length was $207.38 \mathrm{~cm}$ for chemical fertilization compared to $\mathbf{2 1 7 . 6 5}$

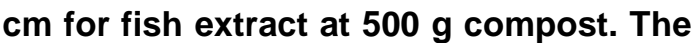
data of the second season followed the same trend, where, chemical fertilization exhibited $204.67 \mathrm{~cm}$ compared to $218.0 \mathrm{~cm}$ for fish extract with $500 \mathrm{~g}$ compost. The differences exhibited significant results. The interaction between moringa extract spray and organic fertilization levels had no significant effect at the two studying seasons.
Fruit yield, data in Table (5) represented early and total yield of cherry tomato plants as affected by foliar application of moringa leaves extract and/or compost levels with fish extract fertilization, compared to chemical fertilization without moringa or compost addition. Moringa leaves extract increased early fruit yield, at season of 2015/2016, there was no significant variation in early fruit yield compared to the non-sprayed plants. However, there was a significant increase in early fruit yield for season 2016/2017 due to moringa extract spraying compared to non sprayed treatment. Moringa extract gave $1.209 \mathrm{~kg} / \mathrm{m}^{2}$ for moringa spray in relation to $1.011 \mathrm{~kg} / \mathrm{m}^{2}$ for non sprayed plants. 
Table (5): Effect of foliar application moringa leaves extract and organic fertilization on early yield (kg/plant) and total yield (kg/plant) of cherry tomato plants.

\begin{tabular}{|c|c|c|c|c|c|c|c|}
\hline \multirow{4}{*}{ Organic fert. } & \multirow[t]{2}{*}{ Ch.1 } & \multicolumn{6}{|c|}{ Fish extract + compost (g/plant) } \\
\hline & & 100 & 200 & 300 & 400 & 500 & Mean \\
\hline & \multicolumn{7}{|c|}{ Early yield $\left(\mathrm{kg} / \mathrm{m}^{2}\right)$} \\
\hline & \multicolumn{7}{|c|}{ First season (2015/2016) } \\
\hline Moringa & 0.991 & 1.347 & 1.297 & 1.179 & 0.962 & 1.159 & 1.156 \\
\hline Without & 0.876 & 0.861 & 1.007 & 0.888 & 0.923 & 1.045 & 0.933 \\
\hline Means & 0.933 & 1.104 & 1.152 & 1.034 & 0.942 & 1.102 & \\
\hline \multirow[t]{2}{*}{ F. test } & \multicolumn{7}{|c|}{$M=N S, C=N S, M \times C=N S$} \\
\hline & \multicolumn{7}{|c|}{ Second season $(2016 / 2017)$} \\
\hline Moringa & 1.055 & 1.317 & 1.332 & 1.253 & 1.070 & 1.227 & $1.209 \mathrm{a}$ \\
\hline Without & 0.960 & 0.963 & 1.042 & 1.044 & 1.046 & 1.013 & $1.011 \mathrm{~b}$ \\
\hline Means & 1.007 & 1.140 & 1.187 & 1.149 & 1.058 & 1.120 & \\
\hline \multirow[t]{3}{*}{ F. test } & \multicolumn{7}{|c|}{$M=*, C=N S, M \times C=N S$} \\
\hline & \multicolumn{7}{|c|}{ Total yield $\left(\mathrm{kg} / \mathrm{m}^{2}\right)$} \\
\hline & \multicolumn{7}{|c|}{ First season (2015/2016) } \\
\hline Moringa & 4.670 & 4.379 & 4.651 & 4.188 & 5.436 & 4.671 & 4.666 \\
\hline Without & 3.765 & 3.437 & 4.222 & 4.112 & 4.697 & 4.714 & 4.158 \\
\hline Means & $4.218 \mathrm{bc}$ & $3.908 \mathrm{c}$ & $4.437 \mathrm{bc}$ & $4.150 \mathrm{bc}$ & $5.047 \mathrm{a}$ & $4.692 \mathrm{ab}$ & \\
\hline \multirow[t]{2}{*}{ F. test } & \multicolumn{7}{|c|}{$\mathrm{M}=\mathrm{NS}, \mathrm{C}={ }^{* *}, \mathrm{M} \times \mathrm{C}=\mathrm{NS}$} \\
\hline & \multicolumn{7}{|c|}{ Second season $(2016 / 2017)$} \\
\hline Moringa & 4.714 & 4.389 & 4.513 & 4.688 & 5.054 & 5.321 & $4.785 \mathrm{a}$ \\
\hline Without & 4.201 & 3.691 & 3.997 & 4.185 & 4.422 & 5.020 & $4.253 \mathrm{~b}$ \\
\hline Means & $4.458 \mathrm{c}$ & $4.040 \mathrm{e}$ & $4.255 d$ & $4.437 \mathrm{C}$ & $4.753 \mathrm{~b}$ & $5.171 \mathrm{a}$ & \\
\hline F. test & \multicolumn{7}{|c|}{$M=* *, C=* *, M \times C=N S$} \\
\hline
\end{tabular}

${ }^{* *},{ }^{*}$ and NS indicate significant differences at $\mathrm{P}<0.01, \mathrm{P}<0.05$ and Not significant, respectively according to F-test.

In the same column, means followed by same letter are not significantly different at $5 \%$ level according to Duncan's test.

The fertilization type clearly affected on early yield of cherry tomato. Organic fertilization (fish extract + different levels of compost) obviously increased early yield over chemical fertilization (without compost). At season of 2015/2016 chemical fertilization (control) produced $0.933 \mathrm{~kg} / \mathrm{m}^{2}$ compared to $1.104,1.152$, $1.034,0.942$ and 1.102 for compost levels, i.e. 100, 200, 300, 400 and 500 g/plant, respectively. The trend at second season was similar trend to the first one.
Total yield of cherry tomato fruits obviously responded to spraying of moringa leaves extract early yield. The data showed 4.666 compared $4.158 \mathrm{~kg} / \mathrm{m}^{2}$ at the first season and 4.785 to $4.253 \mathrm{~kg} / \mathrm{m}^{2}$ at the second season for moringa and not sprayed treatments, respectively. The differences between moringa extract and not sprayed treatment showed significant value at the second season.

Organic fertilization highly increased total yield of tomato especially for the 
high levels of compost (400 and $500 \mathrm{~g} / \mathrm{m}^{2}$ ) compared to chemical treatment for both seasons. The chemical fertilization treatment gave average value of 4.218 compared 5.047 and $4.692 \mathrm{~kg} / \mathrm{m}^{2}$ for 400 and $500 \mathrm{~g} /$ plant compost, respectively, at season 2015/2016. Similar trend appeared at season 2016/2017, where chemical fertilization treatment attained 4.458 compared to 4.753 and $5.171 \mathrm{~kg} / \mathrm{m}^{2}$ for 400 and $500 \mathrm{~g}$ compost/pot, respectively. Although, there was no significant variation for interaction treatment, the highest yield was 5.436 (400 g compost with moringa spray) at season one compared with chemical fertilization and without moringa which gave $3.765 \mathrm{~kg} / \mathrm{m}^{2}$. While, at season two, the highest total yield appeared for organic fertilization (fish extract with $500 \mathrm{~g} /$ pot compost) with moringa spray which gave 5.321 compared $4.201 \mathrm{~kg} / \mathrm{m}^{2}$ with chemical fertilization and without moringa treatment.

Data of the fruit quality depended on some morphological parameter as those shown in Table (6). Average fruit weight positively influenced by foliar spray with moringa leaf extract, but no significant differences was observed at the two growing seasons. Organic fertilization, also, did not exhibit significant variations than the control (chemical fertilization). The interactions between foliar spray with moringa extract and fertilization types had no significant effect on the average of fruit weight.

Table (6): Effect of foliar application moringa leaves extract and organic fertilization on average fruit weight $(\mathrm{g})$, fruit diameter $(\mathrm{mm})$ of cherry tomato fruits.

\begin{tabular}{|c|c|c|c|c|c|c|c|}
\hline \multirow{4}{*}{ Organic fert' } & \multirow[t]{2}{*}{ Ch.1 } & \multicolumn{6}{|c|}{ Fish extract + compost (g/plant) } \\
\hline & & 100 & 200 & 300 & 400 & 500 & Mean \\
\hline & \multicolumn{7}{|c|}{ Average fruit weight (g) } \\
\hline & \multicolumn{7}{|c|}{ First season (2015/2016) } \\
\hline Moringa & 6.49 & 6.83 & 7.41 & 8.47 & 7.09 & 6.81 & 7.18 \\
\hline Without & 6.70 & 6.32 & 6.66 & 6.60 & 7.42 & 6.63 & 6.72 \\
\hline Means & 6.60 & 6.57 & 7.03 & 7.53 & 7.25 & 6.72 & \\
\hline \multirow[t]{2}{*}{ F. test } & \multicolumn{7}{|c|}{$M=N S, C=N S, M \times C=N S$} \\
\hline & \multicolumn{7}{|c|}{ Second season $(2016 / 2017)$} \\
\hline Moringa & 7.08 & 7.29 & 7.17 & 8.36 & 7.45 & 7.03 & 7.40 \\
\hline Without & 6.37 & 6.33 & 6.80 & 6.86 & 7.22 & 6.45 & 6.67 \\
\hline Means & 6.73 & 6.81 & 6.99 & 7.61 & 7.34 & 6.74 & \\
\hline F. test & \multicolumn{7}{|c|}{$M=N S, C=N S, M \times C=N S$} \\
\hline & \multicolumn{7}{|c|}{ Fruit diameter $(\mathrm{mm})$} \\
\hline & \multicolumn{7}{|c|}{ First season (2015/2016) } \\
\hline Moringa & 23.6 & 25.4 & 26.9 & 27.2 & 26.4 & 26.6 & 26.0 \\
\hline Without & 23.6 & 24.9 & 25.8 & 25.7 & 25.3 & 27.5 & 25.46 \\
\hline Means & $23.6 \mathrm{~d}$ & $25.2 \mathrm{c}$ & $26.3 \mathrm{ab}$ & $26.4 \mathrm{ab}$ & $25.8 \mathrm{bc}$ & $27.1 \mathrm{a}$ & \\
\hline \multirow[t]{2}{*}{ F. test } & \multicolumn{7}{|c|}{$\mathrm{M}=\mathrm{NS}, \mathrm{C}={ }^{* *}, \mathrm{M} \times \mathrm{C}=\mathrm{NS}$} \\
\hline & \multicolumn{7}{|c|}{ Second season $(2016 / 2017)$} \\
\hline $\begin{array}{l}\text { Moringa } \\
\text { Without }\end{array}$ & $\begin{array}{l}25.8 \\
24.2\end{array}$ & $\begin{array}{l}24.7 \\
24.3\end{array}$ & $\begin{array}{l}25.8 \\
24.7\end{array}$ & $\begin{array}{l}26.4 \\
25.5\end{array}$ & $\begin{array}{l}26.8 \\
26.4\end{array}$ & 27.3 & $26.1 \mathrm{a}$ \\
\hline Means & $25.0 \mathrm{~d}$ & $24.5 d$ & $25.3 \mathrm{~cd}$ & $26.0 \mathrm{bc}$ & $26.6 \mathrm{ab}$ & $26.9 \mathrm{a}$ & \\
\hline F. test & \multicolumn{7}{|c|}{$M=* *, C=* *, M \times C=N S$} \\
\hline
\end{tabular}

**, * and NS indicate significant differences at $\mathrm{P}<0.01, \mathrm{P}<0.05$ and Not significant, respectively according to F-test.

In the same column, means followed by same letter are not significantly different at $5 \%$ level according to Duncan's test. 
Data of Table 6 illustrated, the average of fruit diameter $(\mathrm{mm})$. The records indicated that there was no significant variations by foliar spray with moringa leaves extract, at the first season, while, at the second growing season, there were significant variations in fruit diameter, which attained $26.1 \mathrm{~mm}$ for moringa extract spray in relation to $25.3 \mathrm{~mm}$ for without moringa one. On the other hand, the organic fertilization significantly increased fruit diameter. The highest values i.e. 27.1 and $26.9 \mathrm{~mm}$ were obtained from high levels of compost (500 $\mathrm{g} /$ pot) compared to 23.6 and $25.0 \mathrm{~mm}$ in the first and the second seasons, respectively,. The interactions between moringa spraying and organic fertilization had no significant effect in both seasons.

Moringa leaves extract had a positive effect on total soluble solids of cherry tomato fruits (Table 7), but the differences were not significant at the first season only. At the second season, shown significant increase in total soluble solids control. Moringa extract spray attained an average $6.03 \%$ in comparison to $5.79 \%$ for not sprayed treatment.

Data of vitamin C were illustrated in Table (7). The moringa extract did not show significant differences than not sprayed treatments in both seasons, although, there were consistent increase for moringa extract spray over not sprayed control, at both seasons, but without significant level.

Otherwise, organic fertilization had a remarkable influence for vitamin C compared to chemical fertilizer (Table 7). A general gradual increase in vitamin C was noted with the increase of compost levels. The chemical fertilization treatment averaged 30.43 compared to average values of compost levels those attained $22.95,38.45,38.13,37.6$ and $44.70 \mathrm{mg} / 100$ $\mathrm{g}$ fruit (fresh weight) for 100, 200, 300, 400 and $500 \mathrm{~g}$ compost/plant, respectively, the differences showed significancy. The trend of the second season was similar to the first one.

The interactions between moringa extract spray and organic fertilization had no significant variations for values of vitamin C. But the moringa spray with the high levels of organic fertilization resulted increase of vitamin C content in tomato fruits compared to no moringa spray and chemical fertilization treatment in both studying seasons.

Organic fertilization with fish extract and different levels of compost, generally, had a positive increase in TSS over chemical fertilization treatment (Table 7). Chemical fertilization at the first season, exhibited an average $5.55 \%$ compared to $6.1,7.02,6.25,5.97$ and 5.78 for 100,200 , 300,400 and $500 \mathrm{~g} /$ pot compost, respectively. The effect of fertilization type, at the second season, gave the same trend. Total soluble solids for chemical fertilization treatment averaged $5.38 \%$ compared to 6.0, 6.9, 6.48, 5.95 and $5.72 \%$ for $100,200,300,400$ and $500 \mathrm{~g}$ compost/pot, respectively. The interaction between moringa extract spray and compost levels showed significant variation at the first season, but did not show significancy at the second one. The treatment of moringa extract spray with $200 \mathrm{~g} /$ pot compost exhibited the highest total soluble solids $(7.17 \%)$ in compared to the lowest value (5.23\%) of the chemical fertilization and without moringa spray treatment (control).

Data of Table (7) showed a heavy increase in titratable acidity due to spray with moringa extract over not sprayed one, and the differences were significant at both seasons. Moringa extract spray averaged $0.388 \%$ in comparison to $0.341 \%$ for not sprayed one. The effect at the second season was similar to first one. Titratable acidity gave 0.380 and $\mathbf{0 . 3 3 8 \%}$ for spray and not sprayed treatments, respectively, and the difference was significant. 
M. Nour El-Din, et al.,

Table (7): Effect of foliar application of moringa leaves extract and organic fertilization on vitamin C, TSS and titratable acidity of cherry tomato fruits.

\begin{tabular}{|c|c|c|c|c|c|c|c|}
\hline \multirow{4}{*}{ Organic fert. } & \multirow[t]{2}{*}{ Ch.1 } & \multicolumn{6}{|c|}{ Fish extract+compost (g/plant) } \\
\hline & & 100 & 200 & 300 & 400 & 500 & Mean \\
\hline & \multicolumn{7}{|c|}{ Vitamin C (mg/100 g fruits) } \\
\hline & \multicolumn{7}{|c|}{ First season $(2015 / 2016)$} \\
\hline Moringa & 33.20 & 23.23 & 40.37 & 40.00 & 38.20 & 42.50 & 36.62 \\
\hline Without & 27.67 & 22.67 & 36.53 & 36.27 & 37.00 & 40.90 & 33.51 \\
\hline Means & $30.43 \mathrm{c}$ & $22.95 \mathrm{~d}$ & $38.45 \mathrm{~b}$ & $38.13 \mathrm{~b}$ & $37.60 \mathrm{~b}$ & $44.70 \mathrm{a}$ & \\
\hline \multirow{2}{*}{ F. test } & \multicolumn{7}{|c|}{$M=N S, C=* *, M \times C=N S$} \\
\hline & \multicolumn{7}{|c|}{ Second season $(2016 / 2017)$} \\
\hline Moringa & 32.20 & 28.43 & 38.67 & 40.59 & 38.20 & 39.90 & 36.33 \\
\hline Without & 29.33 & 26.47 & 30.90 & 34.93 & 35.73 & 36.83 & 32.37 \\
\hline Means & $30.77 \mathrm{c}$ & $27.45 \mathrm{~d}$ & 34.78 b & $37.75 a b$ & $36.97 \mathrm{ab}$ & $38.37 \mathrm{a}$ & \\
\hline \multirow[t]{3}{*}{ F. test } & \multicolumn{7}{|c|}{$M=N S, C=* *, M \times C=N S$} \\
\hline & \multicolumn{7}{|c|}{ Total soluble solids (TSS \%) } \\
\hline & \multicolumn{7}{|c|}{ First season $(2015 / 2016)$} \\
\hline $\begin{array}{l}\text { Moringa } \\
\text { Without }\end{array}$ & $\begin{array}{c}5.87 \mathrm{~cd} \\
5.23 \mathrm{e}\end{array}$ & $\begin{array}{c}6.33 \mathrm{~b} \\
5.87 \mathrm{~cd}\end{array}$ & $\begin{array}{l}7.17 \mathrm{a} \\
6.87 \mathrm{a}\end{array}$ & $\begin{array}{c}6.17 \mathrm{bc} \\
6.33 \mathrm{~b}\end{array}$ & $\begin{array}{c}6.17 \mathrm{bc} \\
5.77 \mathrm{~d}\end{array}$ & $\begin{array}{c}5.80 \mathrm{~cd} \\
5.77 \mathrm{~d}\end{array}$ & $\begin{array}{l}6.25 \\
5.97\end{array}$ \\
\hline Means & $5.55 \mathrm{e}$ & $6.10 \mathrm{bc}$ & $7.02 \mathrm{a}$ & $6.25 \mathrm{~b}$ & $5.97 \mathrm{~cd}$ & $5.78 \mathrm{de}$ & \\
\hline \multirow[t]{2}{*}{ F. test } & \multicolumn{7}{|c|}{$M=N S, C=* *, M \times C=*$} \\
\hline & \multicolumn{7}{|c|}{ Second season $(2016 / 2017)$} \\
\hline Moringa & 5.70 & 6.40 & 7.37 & 6.67 & 6.23 & 5.73 & $6.03 \mathrm{a}$ \\
\hline Without & 5.07 & 5.60 & 6.43 & 6.30 & 5.67 & 5.70 & $5.79 \mathrm{~b}$ \\
\hline Means & $5.38 \mathrm{~d}$ & $6.00 \mathrm{c}$ & $6.90 \mathrm{a}$ & $6.48 \mathrm{~b}$ & $5.95 \mathrm{c}$ & $5.72 \mathrm{~cd}$ & \\
\hline \multirow[t]{3}{*}{ F. test } & \multicolumn{7}{|c|}{$M=*, C=* *, M \times C=N S$} \\
\hline & \multicolumn{7}{|c|}{ Titratable acidity (\%) } \\
\hline & \multicolumn{7}{|c|}{ First season $(2015 / 2016)$} \\
\hline $\begin{array}{l}\text { Moringa } \\
\text { Without }\end{array}$ & $\begin{array}{l}0.607 a \\
0.367 \mathrm{~b}\end{array}$ & $\begin{array}{l}0.373 \mathrm{~b} \\
0.350 \mathrm{~b}\end{array}$ & $\begin{array}{l}0.350 \mathrm{~b} \\
0.333 \mathrm{~b}\end{array}$ & $\begin{array}{l}0.327 b \\
0.320 b\end{array}$ & $\begin{array}{l}0.320 \mathrm{~b} \\
0.337 \mathrm{~b}\end{array}$ & $\begin{array}{l}0.350 \mathrm{~b} \\
0.337 \mathrm{~b}\end{array}$ & $\begin{array}{l}0.388 a \\
0.341 b\end{array}$ \\
\hline Means & $0.487 a$ & $0.362 \mathrm{~b}$ & $0.342 \mathrm{~b}$ & $0.323 \mathrm{~b}$ & $0.328 \mathrm{~b}$ & $0.343 \mathrm{~b}$ & \\
\hline \multirow[t]{2}{*}{ F. test } & \multicolumn{7}{|c|}{$\mathrm{M}=* *, \mathrm{C}=* *, \mathrm{M} \times \mathrm{C}=* *$} \\
\hline & \multicolumn{7}{|c|}{ Second season $(2016 / 2017)$} \\
\hline Moringa & 0.567 a & $0.370 \mathrm{~b}$ & $0.353 \mathrm{~b}$ & $0.327 \mathrm{~b}$ & $0.327 \mathrm{~b}$ & $0.337 \mathrm{~b}$ & $0.380 \mathrm{a}$ \\
\hline Without & $0.353 \mathrm{~b}$ & $0.340 \mathrm{~b}$ & $0.347 \mathrm{~b}$ & $0.323 \mathrm{~b}$ & $0.330 \mathrm{~b}$ & $0.333 \mathrm{~b}$ & $0.338 \mathrm{~b}$ \\
\hline Means & $0.460 \mathrm{a}$ & $0.355 \mathrm{~b}$ & $0.350 \mathrm{~b}$ & $0.325 \mathrm{~b}$ & $0.328 \mathrm{~b}$ & $0.335 \mathrm{~b}$ & \\
\hline F. test & \multicolumn{7}{|c|}{$M=* *, C=* *, M$} \\
\hline
\end{tabular}

${ }^{* *},{ }^{*}$ and NS indicate significant differences at $\mathrm{P}<0.01, \mathrm{P}<0.05$ and Not significant, respectively according to F-test.

In the same column, means followed by same letter are not significantly different at $5 \%$ level according to Duncan's test. 
On the other hand, the chemical fertilization potentially increased titratable acidity over organic fertilization treatments as shown in (Table 7), the chemical fertilization gave $0.487 \%$ in relation to $0.362,0.342,0.323,0.328$ and $0.343 \%$ for compost levels $100,200,300$, and $500 \mathrm{~g}$ compost /pot, at season one. The interaction between moringa spray and compost levels had significant variation through the two studying seasons. The highest value attained for moringa spray with chemical fertilization 0.607 and $0.567 \%$ at seasons one and two, respectively.

Concerning to $\mathrm{N}, \mathrm{P}$ and $\mathrm{K}$ concentration in cherry tomato fruits, results presented in Table (8) showed that spray with moringa leaf extract did not significantly affect $N, P$ and $K$ contents of tomato fruits.
Whilst, the organic fertilization with compost levels plus fish extract fertilization significantly varied than chemical fertilized ones. The highest $N, P$ and $K$ content were $3.98,6.7$ and 5.18 (g/plant) at $400 \mathrm{~g}$ compost/plant with fish extract fertilization compared to 2.60, 5.34 and 4.68 (g/plant) for chemical fertilization. The interactions between moringa leaf extract spray and organic fertilization exhibited a significant influences especially for the treatment of $400 \mathrm{~g}$ compost with fish extract fertigation + moringa leaf extract spray which gave the values $4.16,7.72$ and 5.68 (g/plant) compared to $2.64,5.28$ and 4.56 (g/plant), respectively, for treatment of chemical fertilization without moringa leaf extract spray.

Table (8): Effect of moringa extract and organic fertilization on N, P and K contents (g/plant) of cherry tomato fruits.

\begin{tabular}{|c|c|c|c|c|c|c|c|}
\hline \multirow{4}{*}{ Compost } & \multirow[t]{2}{*}{ Ch.1 } & \multicolumn{6}{|c|}{ Fish extract compost (g/plant) } \\
\hline & & 100 & 200 & 300 & 400 & 500 & Mean \\
\hline & \multicolumn{7}{|c|}{$\mathrm{N}$ content (g/plant) } \\
\hline & \multicolumn{7}{|c|}{ First season $(2015 / 2016)$} \\
\hline Moringa & $2.56 \mathrm{~d}$ & $\begin{array}{l}3.28 \mathrm{c} \\
264 \mathrm{~d}\end{array}$ & $3.84 a b$ & $2.84 \mathrm{a}$ & $4.16 \mathrm{a}$ & $\begin{array}{l}3.64 \mathrm{~b} \\
352 \mathrm{bc}\end{array}$ & $\begin{array}{l}3.4 \\
3.08\end{array}$ \\
\hline Means & $2.60 \mathrm{~d}$ & $2.96 \mathrm{c}$ & $3.54 \mathrm{~b}$ & $2.90 \mathrm{~cd}$ & $3.98 \mathrm{a}$ & $3.58 \mathrm{~b}$ & \\
\hline \multirow[t]{3}{*}{ F. test } & \multicolumn{7}{|c|}{$M=N S, C=* *, M \times C=*$} \\
\hline & \multicolumn{7}{|c|}{$P$ content (g/plant) } \\
\hline & \multicolumn{7}{|c|}{ First season (2015/2016) } \\
\hline Moringa & $5.40 \mathrm{bc}$ & $6.04 \mathrm{bc}$ & $6.20 \mathrm{~b}$ & $5.08 \mathrm{~cd}$ & $\begin{array}{c}7.72 \mathrm{a} \\
5.68 \mathrm{bc}\end{array}$ & $5.44 \mathrm{bc}$ & $\begin{array}{l}5.44 \\
5.60\end{array}$ \\
\hline Means & $5.34 \mathrm{bbc}$ & $5.04 \mathrm{c}$ & $6.00 \mathrm{ab}$ & $4.96 \mathrm{c}$ & $6.70 \mathrm{a}$ & $6.66 \mathrm{a}$ & \\
\hline F. test & \multicolumn{7}{|c|}{$\mathrm{M}=\mathrm{NS}, \mathrm{C}={ }^{* *}, \mathrm{M} \times \mathrm{C}={ }^{* *}$} \\
\hline & \multicolumn{7}{|c|}{ K content (g/plant) } \\
\hline & \multicolumn{7}{|c|}{ First season $(2015 / 2016)$} \\
\hline Moringa & $4.80 \mathrm{bc}$ & $4.48 \mathrm{c}$ & $5.32 \mathrm{ab}$ & $4.40 \mathrm{c}$ & $5.68 \mathrm{a}$ & $4.76 \mathrm{bc}$ & 4.88 \\
\hline Witr & 4.56 bc & $3.32 \mathrm{~d}$ & $4.92 \mathrm{abc}$ & $4.60 \mathrm{bc}$ & $5.60 \mathrm{a}$ & $5.60 \mathrm{a}$ & 4.80 \\
\hline Means & 4.68 bc & $3.90 \mathrm{~d}$ & $5.12 \mathrm{a}$ & $4.50 \mathrm{c}$ & $5.64 \mathrm{c}$ & $5.18 \mathrm{a}$ & \\
\hline
\end{tabular}

${ }^{* *},{ }^{*}$ and NS indicate significant differences at $\mathrm{P}<0.01, \mathrm{P}<0.05$ and Not significant, respectively according to F-test.

In the same column, means followed by same letter are not significantly different at $5 \%$ level according to Duncan's test. 


\section{DISCUSSION}

Moringa oleifera is a wide broad cultivated plant, it is easy to be cultivated through wide broad environmental area. Moringa leaves contain a high content of elements and vitamins. It contains $25 \%$ protein, $0.5 \%$ methionine and it is also an important source of antioxidant (Bashir et al., 2014). It is found, also, that contains cytokinins related hormones (Fugil, 2000). Moringa leaves contains zeatin hormone with high values (from 5 to $200 \mathrm{mcg} / \mathrm{g}$ moringa leaves) (Culver et al., 2012).

For these characteristics of moringa leaves, the foliar spray with moringa leaves extract had positive influences on tomato growth and yield. Whereas, Culver et al. (2012) found that foliar spray with leaves moringa extract increased rates of tomato growth under greenhouse cultivation, it potentially increased fruit yield. Similarly Matthew (2016) found that foliar spray of pepper plants with moringa extract at concentration of 1:20 each two weeks gave the highest fruits yield and the highest fruits number/plant compared to not sprayed plants. Additionally, it improved the other growth like stem thickness number of leaves/plant and stem length.

On the other hand, the present study indicated that organic fertilization with the different compost levels with fertigation with fish extract (1:100) gave a high fruits yield for cherry tomato as well as improving other growth characteristics such as stem length, number of leaves per plant, number of fruits/plant ... etc. Therefore, the application of organic fertilization in soilless systems contributes an important feature for production of organic foods, whereas, Treadwell et al. (2007) remembered that chemical fertilized plant products are rejected under the NOP (National organic program). But plant nutrients may supplied as plant-animal-based organic fertilizers as well as mind minerals.
Lazcano et al. (2009) used additions of compost and vermicompost on peatmoss medium, they found that compost concentrations till $20 \%$ added on peatmoss improved tomato growth and fruits yield. They also, found that substitution of peatmoss with vermicompost till $100 \%$ improves these characteristics of tomato. Atiyeh et al. (2000) indicated a similar results, whereas, they substituted Metro-Mix360 medium with $10 \%$ or $20 \%$ Vermicompost increased tomato growth, because of the high content of elements present in vermicompost.

Dresbell (2004) reported in his study on alternative media for organic greenhouse production, that compost may be a suitable alternative to natural substrate in case of organic fertilization. But, when compost is used as growing medium in organic greenhouse production, a number of requirements should be fulfilled: first, the compost structure, water retention, air filled porosity and volume weights must be suitable, the particle size distribution must be in the range $30-300 \mu \mathrm{m}$. These will retain water, but not bind it tightly, secondly: nutritional quality of compost important parameter (Payne, 1988).

The use of fish extract, in the present investigation, help in supply the tomato plants with their needs from elements, but from organic source. It was noted that the use of fish extract with the dilution of 1:10 in addition to compost amendments contributes for supply the plant with their most needs of elements when compared to the plant fertigated with the recommended dose of chemical nutrients as fertigation (Tzortzakis and Economakis, 2008). Whereas, FernandezSalvador et al. (2015) used different sources of liquid organic fertilizers for production of organic blackberry like fish waste digestion blend and a corn steep liquor $(2.5 \mathrm{~N}: 1.1 \mathrm{P}: 1.2 \mathrm{~K})$ and also 
soluble and molasses blend (4 N: $0.0 \mathrm{P}$ : $1.2 \mathrm{~K}$ ) and they mentioned that these two organic fertilizers supplied sufficient nutrients to meet plant needs except $\mathrm{Ca}$ and $B$.

Plant contents of macro-elements in leaves and fruits varied with type and level of fertilization. Tomato fruit contents of $\mathrm{N}$, $\mathrm{P}$ and $\mathrm{K}$ were found by Baldantoni et al. (2015) which the increase due to application of compost levels, the most effective level was 45 tons/ha. Kochakinezhad et al. (2012) remembered that the addition of different types of compost like spent mushroom and manure compost increased fruit contents from $P$ and $K$. Whilst, the treatment with moringa leaf extract did not give significant increase in these macroelement than control plants ( $N, P$ and $K$ contents). These results in confirm with the results of the present investigation (Culver et al., 2012 and Bashir et al., 2014) on tomato plants.

In conclusion, the soilless agriculture is very important, especially for using bare lands and house roofs in food production. Cherry tomato planted in vermiculite media with compost levels gave grater results. The organic fertilization with compost and fertigation with fish extract at concentration with 1:100 water, increased yield components and improved fruit quality as well as other plant growth parameters.

\section{REFERENCES}

Abdel-Razzak, H., M. Wahab-Allah, A. Ibrahim, M. Alenazi and A. Alsadon (2016). Response of cherry tomato to irrigation levels and fruit pruning under greenhouse conditions. J. Agr. Sci. Tech., 18: 1091-1103.

A.O.A.C. (1990). Official methods of analysis. Association of Official Analytical Chemists. 15 ${ }^{\text {th }}$ ed. Washington DC, USA.
Atiyeh, R.M., N.Q. Arancon, C.A. Edwards and J.D. Metzger (2000). Influence of earthworm-processed pig manure on the growth and yield of greenhouse tomatoes. Bioresource Technology, 75: $175-180$.

Baldantoni, D., A. Bellino and A. Alfani (2015). Soil compost amendment enhances tomato (Solanum lycopersicum) quality. J. Sci. Food Agric., 96: 4082-4088.

Bashir, K.A., J.A. Bawa and I. Mohammed (2014). Efficacy of leaf extract of Drumstick tree (Moringa oleifera LAM) on the growth of local tomato (Lycopersicon esculentum). IOSR Journal of Pharmacy and Biological Sciences, 9(4): 74-79.

Culver, M., T. Fanue and A.Z. Chiteka (2012). Effect of moringa extract on growth and yield of tomato. Greener Journal of Agricultural Sciences, 2(5): 207-211.

Dresbell, D.B. (2004). Optimization of growing media for organic greenhouse production. Ph.D. Thesis, Danish Institute of Horticulture, The Royal Veterinary and Agricultural University.

Fernandez-Salvador, J., B.C. Strik and D.R. Bryla (2015). Liquid corn and fish fertilizers are good options for fertigation in blackberry cultivars grown in an organic production system. HortScience, 50(2): 225-233.

Fuglie, L.J. (2000). New uses of moringa studied in Nicaragua, ECHO's Technical Network Site-networking global hunger solution. ECHO, Nicaragua.

Howladar, S.M. (2014). A novel moringa (Moringa oleifera) leaf extract can mitigate the stress effects of salinity and cadmium in bean (Phaseolus vulgaris L.) plants. Ecotoxicology and Environmental safety, 100: 69-75.

Jackson, J. and Strelec (1967). Soil Chemical analysis. Prentice Hall of India, Private Limited, New Delhi, 115 pp. 
King, E.J. (1951). Micro-analysis in medical biochemistry, $2^{\text {nd }}$ Ed. Churchill, London.

Kochakinezhad, H., G.H. Peyvast, A.K. Kashi, J.A. Olfali and A. Asadii (2012). A comparison of organic and chemical fertilizers for tomato production. J. Organic systems. 7(2): 14-25.

Lazcano, C., J. Arnold, A. Tato, J.G. Zaller and J. Dominguez (2009). Compost and vermicompost as nursery pot components: Effects on tomato plant growth and morphology. Spanish Journal of Agricultural Research, 7: 944-951.

Matthew, A. (2010). Moringa leaf extract on the growth and yield of pepper (Capsicum annuum L.). APPN Journal of Agricultural and Biological Science, 3: 107-109.

Mohamman, M.A. and S.G. Mohammed (2014). Effects of aqueous extract of moringa (Moringa oleiera LAM.) and nitrogen rates on the contribution of some physiological and yield attributes to grain yield of sesame (Sesamum indicum L.). II. Scientific Papers Series A. Agronomy, Volume LVII.

Nair, A., M. Ngouajio and J. Biernbaum (2011). Alfalfa-based organic tomato transplant production. HortScience, 46(2): 253-259.

Olle, M., M. Ngouajio and A. Siomos (2012). Vegetable quality and productivity as influenced by growing medium: a review. Zemdir-Byste= Agriculture, 99(4): 399-408.
Payne, D. (1988). The behavior of water in soil. In: Wild, A. (Ed.), Russell;s Soil conditions \& plant growth. Longman Scientific \& Technical, pp. 315-337.

Pinho, L., A.C. Almeida, C.A. Costa, M.C.D. Paes, M.B. Gloria and R.M. Souza (2011). Nutritional properties of cherry tomatoes harvested at different times and grown in an organic cropping. Horticultura Brasileira, 29: 205-211.

Pregel, F. (1945). Quantitative organic micro-analysis. $4^{\text {th }}$ Ed., J.A. Churchill, Lotoi, London.

Rady, M.M., F. Gamal, A.M. Mohamed and H.M. Yasmin (2015). Integrated application of salicylic acid and Moringa oleifera leaf extract alleviates the salt-induced adverse effect in common bean plants. Journal of Agricultural Technology, 11(7): 15951614.

Treadwell, D.D., G.J. Hochmuth, R.C. Hochmuth, E.H. Simmone, L.L. Davis, W.L. Laughlin, Li T. Olczyk, R.K. Sprenkel and L.S. Osborne (2007). Nutrient management in organic greenhouse herb production: where are we now? Hort Technology, 17: 461466.

Tzortzakis, N.G. and C.D. Economakis (2008). Impact of substrate medium on tomato yield and fruit quality in soilless cultivation. Hort. Sci., 35(2): 83-89.

Zhai, Z. (2009). Organic fertilizers for greenhouse tomatoes: productivity and substrate microbiology. HortScience, 44(3): 800-809. 
أهمية التسميل بالكومبوست والرش بمستخلص المورينجا على إنتاجية ونوعية الطماطم

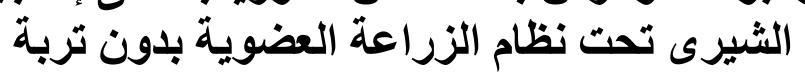

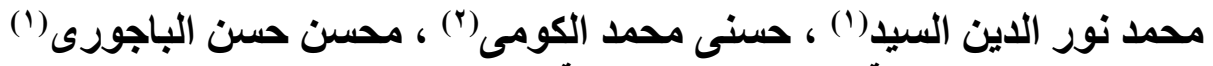

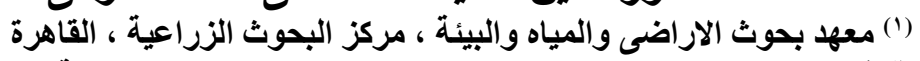

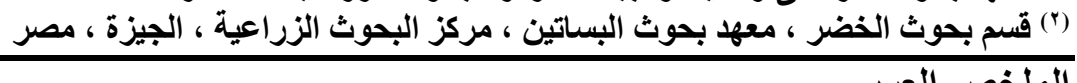

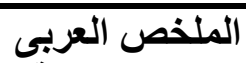

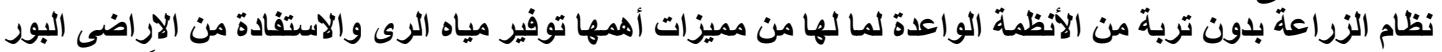

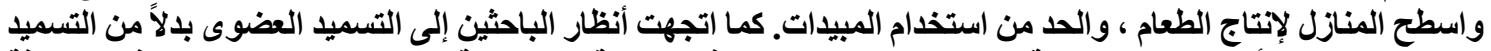

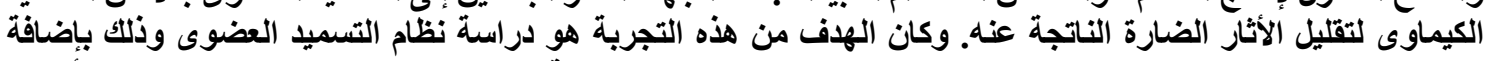

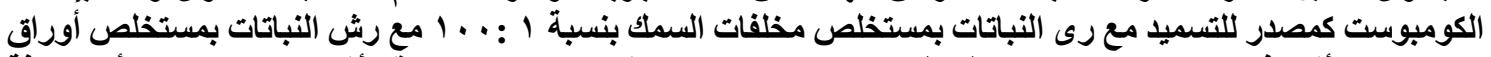

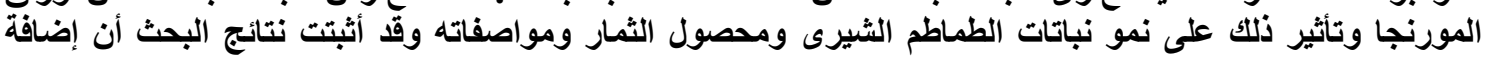

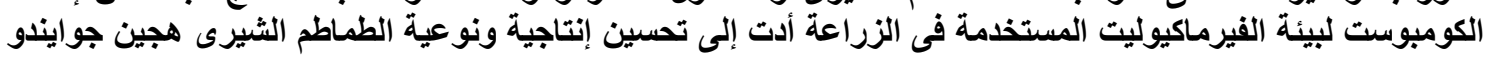

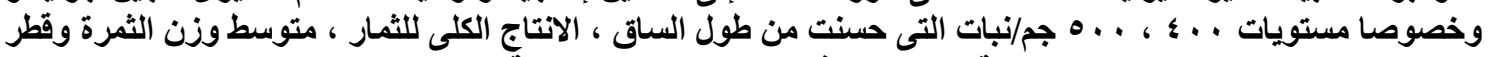

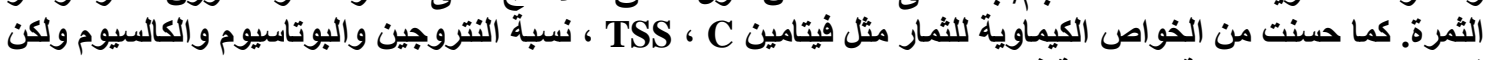
قللت سمك الساق و نسبة الحموضة فئ في الثمار الثمار.

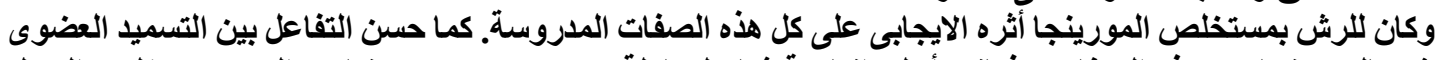

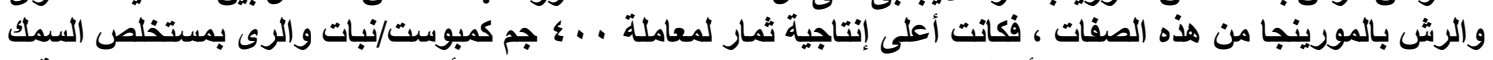

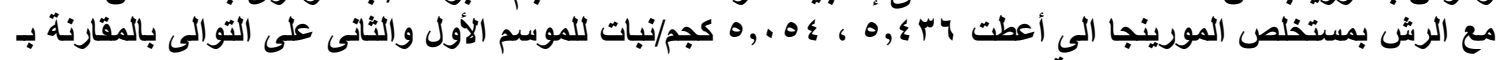

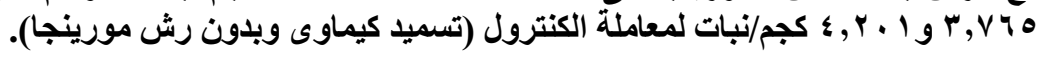

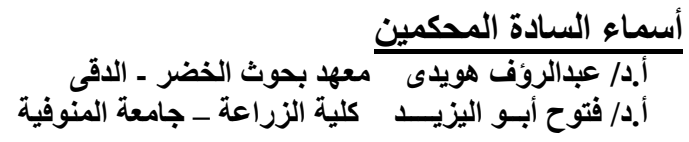

